\title{
Confirmation of Xanthomonas citri subsp. citri causing citrus canker in Timor-Leste
}

\author{
J. D. Ray ${ }^{1,2}$ - R. K. Taylor $^{3}$ - R. L. Griffin ${ }^{3}$ - R. S. James ${ }^{2}$ - C. Dale ${ }^{4}$ - A. Ximines ${ }^{5}$. \\ L. M. Jones ${ }^{6}$
}

Received: 19 May 2017 / Accepted: 18 July 2017 /Published online: 24 August 2017

(C) Australasian Plant Pathology Society Inc. 2017

\begin{abstract}
The bacterium Xanthomonas citri subsp. citri, which causes the disease citrus canker, has been confirmed and reported for the first time in Timor-Leste. Herbarium collections indicate citrus canker has been present since at least 2006. The identity of $X$. citri subsp. citri has been confirmed using biochemical, and molecular tests, and by completion of Koch's postulates.
\end{abstract}

Keywords Citrus canker - Citrus x aurantifolia .

Xanthomonas citri subsp. citri · Timor-Leste · East Timor

Citrus canker is a serious bacterial disease that produces characteristic symptoms consisting of erupting light brown pustules, which become rough, cracked and corky, surrounded by a water soaked margin that usually has a characteristic yellow halo. The disease infects all above ground plant parts making trees less productive and fruit unmarketable, serious infections can also lead to defoliation and premature fruit drop (Anon. 1997).

J. D. Ray

j.ray@uq.edu.au

1 Present address: Centre for Plant Science, The University of Queensland, Brisbane, QLD 4072, Australia

2 Department of Agriculture and Water Resources, PO Box 37846, Winnellie, NT 0821, Australia

3 Plant Health and Environment Laboratory, Ministry for Primary Industries, PO Box 2095, Auckland 1140, New Zealand

4 Department of Agriculture and Water Resources, GPO Box 858, Canberra ACT 2601, Australia

5 National Directorate of Quarantine and Biosecurity, Ministry of Agriculture and Fisheries, Comoro, Dili, Timor-Leste

6 Department of Agriculture and Water Resources, PO Box 96 International Airport, Qld 4870, Cairns, Australia
The citrus canker bacterium has been re-classified several times and was previously grouped into five strains of Xanthomonas campestris pv. citri (A,B,C,D,E). The A strain (Asiatic) is now known as Xanthomonas citri subsp. citri. The other strains have been reclassified as $X$. fuscans subsp. aurantifolii (groups B, C and D) and X. alfalfa subsp. citrumelonis (group E) (Schaad et al. 2006; Vauterin et al. 1995). X. citri subsp. citri infects Citrus spp., some other Rutaceae and one non Rutaceae host Lansium domesticum (Anon. 1997). X. citri subsp. citri has been recorded in many parts of the world including Africa, South America and Asia including the neighboring country of Indonesia although it probably originated from South East Asia (Anon. 1997). There are also variants of $X$. citri subsp. citri that show a restricted host range, $\mathrm{A}^{*}$ strains causes a disease on Mexican lime in parts of the middle east and Asia and the $A^{\mathrm{w}}$ strains attacks only Key or Mexican limes and Citrus macrophylla in Florida (Cubero and Graham 2002; Verniere et al. 1998).

Plant health surveys were conducted over several years by the Timor-Leste Ministry of Agriculture and Fisheries and the Australian Government Department of Agriculture and Water Resources in Timor-Leste (East Timor). These surveys aimed to identify potential disease threats to Timor-Leste and Australia and to increase the knowledge of plant pests in Timor-Leste. During surveillance from 2006 to 2016 the leaves of citrus plants showing characteristic symptoms of citrus canker were collected (Table 1). These specimens were dried in a plant press, imported into Australia under permit and irradiated at $25 \mathrm{kGray}$ upon arrival. DNA was extracted from the lesions using the DNeasy Plant Mini Kit (QIAGEN) and amplified with $\mathrm{J}$-pth1/J-pth2 primers following the methods of Cubero and Graham (2002). This assay is known to detect the citrus canker pathogens of $X$. citri subsp. citri and X. fuscans subsp. aurantifolii (Cubero and Graham 2002). Samples that produced a diagnostic PCR amplicon of 
Table 1 Citrus leaves showing characteristic canker symptoms were collected during plant health surveillance in Timor-Leste.

These herbarium specimens tested positive for Xanthomonas citri subsp. citri using a molecular assay with the J-pth1/J-pth2 primers described in Cubero and Graham (2002)

\begin{tabular}{llll}
\hline Sample & Host & Date collected & Location / District \\
\hline PS1169 & Citrus sp. & $27 / 03 / 2006$ & Sau village, Manatuto \\
JR1063 & Citrus x aurantifolia & $24 / 03 / 2011$ & Wailacama, Vemase, Baucau \\
JR2811 & Citrus hystrix & $10 / 05 / 2013$ & Watubo, Baucau \\
JR2819 & Citrus x aurantifolia & $12 / 05 / 2013$ & Lospalos, Lautem \\
GS238 & Citrus x aurantifolia & $16 / 05 / 2013$ & Watubo, Baucau \\
LMJ648 (T15_05499) & Citrus x aurantifolia & $06 / 05 / 2015$ & Manleuana, Dili \\
JR3224 & Citrus x aurantifolia & $17 / 03 / 2016$ & Aelafa, Daudere, Lautem \\
JR3265 & Citrus x aurantifolia & $21 / 03 / 2016$ & Sabuli, Metinaro, Dili \\
GS16-146 & Citrus sp. & $23 / 03 / 2016$ & Manleuana, lisbutac II, Dili \\
\hline
\end{tabular}

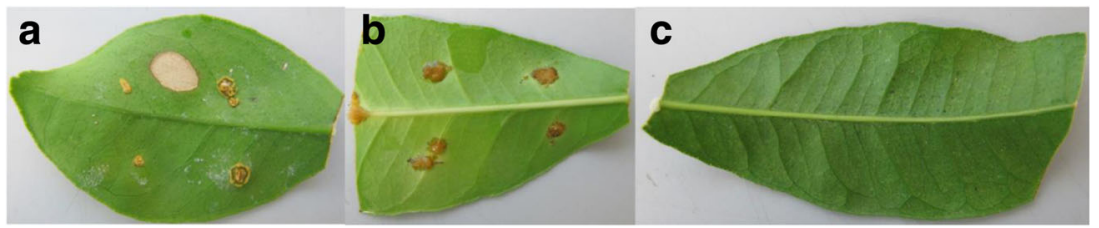

Fig. 1 Symptoms on detached Citrus leaves inoculated with Xanthomonas citri subsp. citri isolate from Timor Leste (ICMP 22013). a. Infected Citrus sinensis leaf; b. Infected Citrus aurantifolia leaf; c. Uninfected Citrus aurantifolia leaf (negative control)

approximately 197 base pairs were considered positive for citrus canker (Table 1).

To confirm the identity of citrus canker a sample of Citrus aurantifolia (LMJ 648) was collected from Manleuana, Dili, Timor-Leste in May 2015 and sent to New Zealand for further testing, under relevant biosecurity protocols. Isolations of the bacterium from infected leaf material were conducted in a containment laboratory (Physical containment level 2 with additional controls) by streaking suspensions of macerated diseased leaf tissue onto semi-selective media developed by Pruvost et al. (2005) and Yeast peptone glucose agar media. Mucoid pale yellow bacterial colonies were consistently produced following $48 \mathrm{~h}$ incubation at $25{ }^{\circ} \mathrm{C}$. All colonies were gram negative, oxidase negative, catalase positive. Testing of DNA extracted from plant tissue and cultures with specific real-time PCR assays, developed by Mavrodieva et al. (2004) and Park et al. (2006) confirmed that these isolates were $X$. citri subsp. citri. The genetic diversity of these strains was assessed by an analysis of Irp gene sequences as described by Cubero and Graham (2004). A phylogenetic analysis of Irp sequences of $X$. citri subsp. citri and other Xanthomonas strains that occur on citrus show that the TimorLeste strains cluster with the $X$. citri subsp. citri type strain and distinguish them from the atypical milder $X$. citri subsp. citri pathotypes $\left(\mathrm{A}^{*}\right.$ and $\left.\mathrm{A}^{\mathrm{W}}\right)$ (Fig. 1). Representative cultures have been stored in the International Collection of Micro-organisms from Plants (ICMP), Landcare Research, Auckland, New Zealand, under ICMP 22013, 22,014 and 22,015.

Pathogenicity tests were performed with three different isolates (ICMP 22013, 22,014, 22,015) on young detached

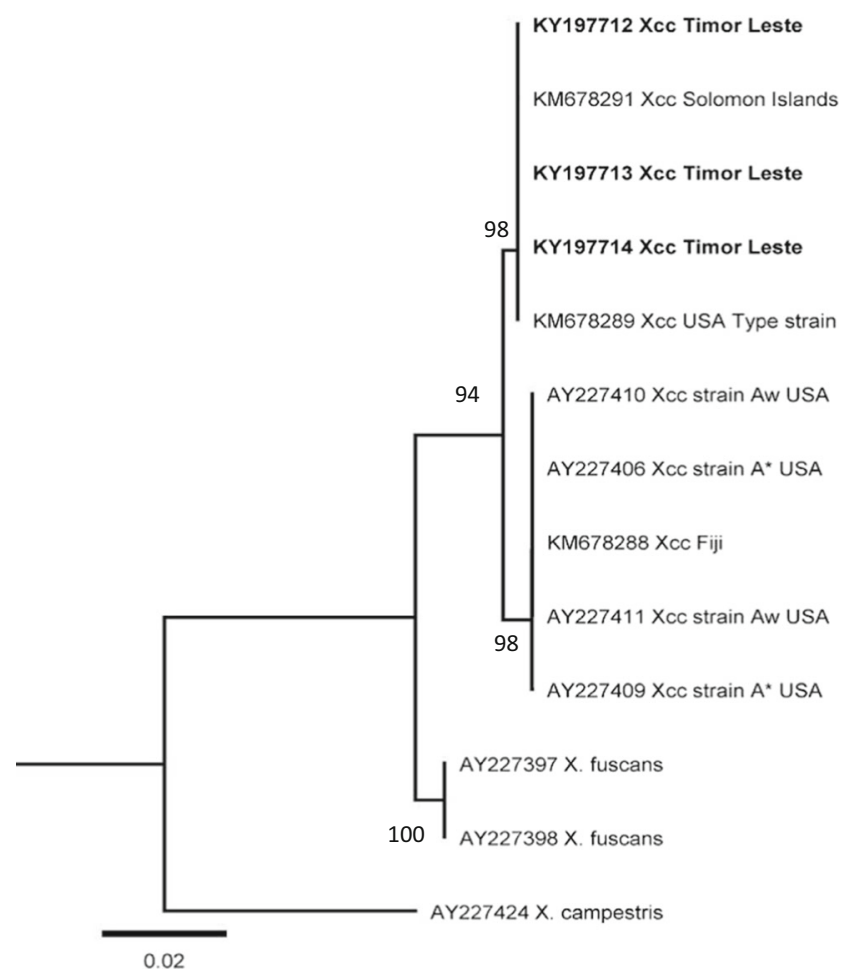

Fig. 2 Maximum likelihood tree illustrating the phylogenetic relationships between the Timor-Leste Xanthomonas citri subsp. citri (Xcc) strains (in bold type) and other Xcc strains. Phylogenetic analyses of the Irp gene was performed via Geneious Pro 9.5.1 (Biomatters, Auckland, New Zealand) using RAxML 7.2.8 for tree construction. Topology was rooted with $X$. campestris and bootstrap values from 10,000 replicates are given at the nodes. Sequences produced in this study are deposited in Genbank under accession numbers KY197712 - KY197714 
leaves of orange and lime. Twenty $\mu$ of bacterial suspension $\left(10^{7} \mathrm{cfu} / \mathrm{ml}\right)$ from each isolate was inoculated on the surface of healthy leaves by pricking through the drops using sterile needles. Leaves were incubated in humid conditions at $25^{\circ} \mathrm{C}$. Pustule -like symptoms developed after 10 days (Fig. 2). Bacterial colonies identified as $X$. citri subsp. citri were reisolated from the lesion fulfilling Koch's postulates.

Citrus canker caused by the virulent bacteria $X$. citri subsp. citri (broad host range) has been confirmed as present in Timor-Leste. Citrus canker has been present since at least 2006 and is fairly widely distributed (Table 1.). However, unconfirmed survey records indicate the bacterium was present in 2002. The majority of Timor-Leste is comprised of subsistence farmers who experience a 'hungry season' each year while waiting for maize and rice crops to mature (Costa et al. 2013). Citrus is a relatively minor crop but important as it provides nutrition and generates some income. Citrus canker can cause substantial economic losses to trees grown in commercial orchards; however, the impact on trees grown in isolated subsistence or domestic situations like much of TimorLeste can be much lower (Gottwald et al. 2002). Canker free nurseries providing disease free planting materials and grove sanitation are recommended for reducing the prevalence of the disease in Timor-Leste.

Acknowledgements Timor-Leste Ministry of Agriculture and Fisheries and the Australian Government Department of Agriculture and Water Resources are thanked for funding and coordinating the surveys in Timor-Leste. Valente Quintao MAF TL is gratefully thanked for his support over many years of surveys.

\section{References}

Anon. (1997) Data sheets on quarantine pests; Xanthomonas axonopodis pv. citri. In: Smith IM, McNamara DG, Scott PR, Holderness M (eds) Quarantine pests for Europe, 2nd edn. CABI, Wallingford, UK

Costa M, Lopes M, Ximenes A, Rosario A, Spyckerelle F, Williams R, Nesbitt H, Erskine W (2013) Household food insecurity in TimorLeste. Food security 5:83-94

Cubero J, Graham JH (2002) Genetic relationship among worldwide strains of Xanthomonas causing canker in citrus species and design of new primers for their identification by PCR. Appl Environ Microbiol 68:1257-1264

Cubero J, Graham JH (2004) The leucine-responsive regulatory protein (lrp) gene for characterization of the relationship among Xanthomonas species. Int J Syst Evol Microbiol 54:429-437

Gottwald TR, Graham JH, Schubert TS (2002) Citrus canker: the pathogen and its impact. Plant health progress. Available at http://hdl. Handle.Net/10113/11855 [verified 22 September 2010]

Mavrodieva V, Levy L, Gabriel DW (2004) Improved sampling methods for real-time polymerase chain reaction diagnosis of citrus canker from field samples. Phytopathology 94:61-68

Park DS, Hyun JW, Park YJ, Kim JS, Kang HW, Hahn JH, Go SJ (2006) Sensitive and specific detection of Xanthomonas axonopodis pv. citri by PCR using pathovar specific primers based on hrpW gene sequences. Microbiol Res 161:145-149

Pruvost O, Roumagnac P, Gaube C, Chiroleu F, Gagnevin L (2005) New media for the semiselective isolation and enumeration of Xanthomonas campestris pv. mangiferaeindicae, the causal agent of mango bacterial black spot. J Appl Microbiol 99:803-815

Schaad NW, Postnikova E, Lacy G, Sechler A, Agarkova I, Stromberg PE, Stromberg VK, Vidaver AK (2006) Emended classification of xanthomonad pathogens on citrus. Syst Appl Microbiol 29:690-695

Vauterin L, Hoste B, Kersters K, Swings J (1995) Reclassification of Xanthomonas. Int J Syst Bacteriol 45:472-489

Verniere C, Hartung JS, Pruvost OP, Civerolo EL, Alvarez AM, Maestri P, Luisetti J (1998) Characterization of phenotypically distinct strains of Xanthomonas axonopodis pv. citri from Southwest Asia. Eur J Plant Pathol 104:477-487 